\title{
Determinan Islamic Social Report Disclosure Industri Barang Konsumsi yang terdaftar di Indeks Saham Syariah Indonesia (ISSI)
}

\section{The Determinants of Islamic Social Report Disclosure in Listed Indonesia Sharia Index (ISSI) Consumer Goods Industries}

\author{
Nur Nugrahani Setiawati ${ }^{1 *}$, Sigid Eko Pramono ${ }^{2}$, Endri ${ }^{2}$ \\ ${ }^{1)}$ Konsentrasi Akuntansi Syariah Pascasarjana STEI TAZKIA Bogor \\ ${ }^{2)}$ Pascasarjana STEI TAZKIA Bogor
}

\begin{abstract}
This study aims to analyze the influence of company size, muslims on board, women on board, company age, foreign ownership, Islamic securities, profitability, liquidity, leverage against Islamic Social Report disclosures of listed Consumer Goods Industries in Indonesia Sharia Stock Index (ISSI) in 2011-2017. The sample consists of 23 listed Consumer Goods Industries in Indonesia Sharia Index (ISSI) in 2011-2017. Annual reports were analyzed by content analysis method and Panel Data Regression Analysis Model was used to test hypotheses. The analysis shows that company's size, company's age, profitability have a significant positive effect on disclosure of the Islamic Social Report (ISR) in Consumer Goods Industries. Meanwhile, muslims on board, women on board, foreign ownership, Islamic securities, liquidity, leverage have no significant effect towards the disclosure of Islamic Social Report on Consumer Goods Industries.
\end{abstract}

Keywords: Islamic social, report, disclosure, industries.

\begin{abstract}
ABSTRAK
Penelitian ini bertujuan untuk menganalisis pengaruh ukuran perusahaan, muslim di dewan direksi, wanita di dewan direksi, usia perusahaan, kepemilikan asing, efek syariah perusahaan, profitabilitas, likuiditas, leverage, terhadap pengungkapan Islamic Social Report pada industri barang konsumsi yang terdaftar di Indonesia Sharia Stock Index (ISSI) dalam rentang tahun 2011-2017. Sampel terdiri dari 23 industri barang konsumsi yang terdaftar di Indeks Syariah Indonesia (ISSI) rentang waktu 2011-2017. Laporan tahunan dianalisis dengan content analysis dan Model Analisis Regresi Data Panel digunakan untuk menguji hipotesis. Analisis menunjukkan bahwa ukuran perusahaan, usia perusahaan, profitabilitas, berpengaruh positif signifikan terhadap pengungkapan Islamic Social Report (ISR) pada industri barang konsumsi. Sementara itu, muslim di dewan direksi, wanita di dewan direksi, kepemilikan asing, efek syariah perusahaan, likuiditas, leverage tidak berpengaruh signifikan terhadap pengungkapan Islamic Social Report pada industri barang konsumsi.
\end{abstract}

Kata Kunci: Islamic social reporting, pengungkapan, industry.

*Corresponding author

Alamat e-mail: nurnugrahani77@gmail.com 


\section{PENDAHULUAN}

Praktik dan pengungkapan CSR di Indonesia mendapat dukungan dari pemerintah dengan dikeluarkannya Undang-Undang Nomor 40 Tahun 2007 Pasal 74 mengenai laporan tahunan harus memuat beberapa informasi, salah satunya laporan pelaksanaan tanggung jawab sosial dan lingkungan serta Undang-Undang No. 25 tahun 2007 pasal 15(b) dan pasal 16 (d) tentang Penanaman Modal (Syukron, 2015). Perusahaan yang mengungkapan CSR berarti perusahaan tersebut memberikan informasi yang bertanggung jawab secara sosial, dimana hal ini dapat mempengaruhi secara positif kinerja pasar dan sekaligus berkontribusi pada pembentukan keberadaan perusahaan dengan kelompok sasaran yang spesifik dan masyarakat umum, yang akhirnya dapat dipastikan terjadi kontrak sosial antara perusahaan dan masyarakat di mana perusahaan beroperasi (Mathews, 1995).

Haniffa (2002) menyatakan bahwa kerangka konseptual Islamic Social Reporting sesuai ketentuan syariah tidak hanya membantu pengambilan keputusan bagi pihak muslim melainkan juga membantu pihak internal perusahaan dalam melakukan pemenuhan kewajibannya terhadap Allah SWT dan masyarakat. Othman et al. (2009) mengembangkan indeks pengungkapan yang relevan pada Islamic Social Reporting (ISR) di Malaysia. Indeks ISR merupakan tolok ukur pelaksanaan tanggung jawab sosial perusahaan syariah yang berisi item-item standar CSR yang ditetapkan oleh AAOIFI (Accounting and Auditing Organization for Islamic Financial Institutions) yang dikembangkan lebih lanjut oleh para peneliti mengenai item-item CSR yang seharusnya diungkapkan oleh suatu entitas Islam.

Othman dan Thani (2010) menyatakan perkembangan pasar modal syariah yang begitu cepat membuat perusahaan-perusahaan yang masuk Daftar Efek Syariah diharapkan untuk menyajikan suatu dimensi religi dalam pengungkapan laporan tahunan dalam rangka memberikan manfaat bagi pemangku kepentingan. Sehingga pasar modal yang tumbuh pesat ditambah maraknya perusahaan yang melakukan pengungkapan pertanggungjawaban sosial, seharusnya sebagai pelaku ekonomi syariah juga harus melaporkan tanggung jawab sosial yang berbasis syariah. Pasar modal syariah yang berisi perusahaan-perusahaan yang memiliki saham syariah dari beberapa sektor industri dan non industri, seharusnya mengungkapkan Islamic Social Reporting sebagai bentuk tanggung jawab sosialnya.

Hasil dari beberapa penelitian menyatakan terdapat persamaan dan perbedaan faktor-faktor yang mempengaruhi pengungkapan ISR di perusahaan manufaktur, non manufaktor dan bank syariah. Tabel 1 menunjukkan perbandingan penelitian penerapan pengungkapan CSR dan ISR di Indonesia dan negara lain. Berdasarkan penelitian-penelitian yang telah dilakukan, terdapat beberapa faktor yang dapat mempengaruhi pengungkapan CSR dan ISR, serta terdapat ketidakkonsistenan hasil penelitian tentang faktor-faktor yang mempengaruhi pengungkapan ISR. Selain itu, banyak penelitian hanya memfokuskan pengungkapan ISR pada bank syariah dan tidak pada perusahaan manufaktur dan non manufaktur. Dengan demikian, dipandang perlu untuk melakukan pengujian lebih lanjut terhadap faktor-faktor yang mempengaruhi pengungkapan ISR jika diterapkan pada lingkungan dan waktu yang berbeda dari penelitian sebelumnya tersebut. Oleh karena itu, penelitian ini menguji kembali faktor-faktor yang mempengaruhi pengungkapan ISR dengan menggunakan indeks ISR pada lingkungan yang lebih spesifik yaitu perusahaan sektor industri konsumsi yang terdaftar di Indonesia Sharia Stock Index (ISSI). 
Nilai indeks ISR diperoleh dengan metode analisis isi (content analysis) pada laporan tahunan perusahaan. Penelitian ini menggunakan indeks pengungkapan tanpa pembobotan, yaitu melihat ada tidaknya item informasi yang mungkin diungkapkan dalam laporan tahunan perusahaan. Item-item tersebut tidak diberi bobot yang berbeda berapapun banyaknya item yang diungkapkan dalam setiap pokok pengungkapan. Sebab yang diukur adalah tingkat kelengkapan pengungkapan informasi. Indeks ISR dalam penelitian ini terdiri dari 43 pokok pengungkapan yang tersusun dalam enam tema sesuai penelitian Rohana Othman et al. (2009) yang dimodifikasi dengan item pengungkapan pada penelitian Amilia Nurul Raditya (2009), Tika Astuti (2013), Tria Karina Putri, Etna Nur Afri Yuyetta (2014), Grigoris Giannarakis (2014). Sehingga Indeks ISR dalam penelitian ini terdiri dari 47 pokok pengungkapan yang tersusun dalam enam tema, yaitu tema pembiayaan dan investasi, tema produk dan jasa, tema karyawan, tema masyarakat, tema lingkungan, dan tema tata kelola perusahaan. Masing-masing pokok pengungkapan dalam penelitian ini memiliki nilai 1 atau 0 . Nilai 1 akan diberikan apabila pokok pengungkapan dalam ISR terdapat dalam laporan tahunan (annual report) perusahaan dan nilai 0 akan diberikan apabila sebaliknya. Nilai-nilai tersebut kemudian dijumlahkan baik menurut masing-masing tema maupun secara keseluruhan. Sehingga nilai terbesar adalah 47 dan nilai terkecil adalah 0 untuk setiap perusahaan dalam setiap tahun. Setelah pemberian nilai (scoring) pada indeks ISR selesai dilakukan, maka besarnya disclosure level dapat ditentukan dengan rumus berikut:

\section{Disclosure Level $=\underline{\text { Jumlah } \text { score disclosure yang dipenuhi }}$}

\section{Jumlah skor maksimal}

Variabel independen yang digunakan dalam penelitian ini adalah variabel ukuran perusahaan (company size) yang mengacu pada penelitian Othman et al. (2009). Novrizal dan Fitri (2016), Putri dan Yuyetta (2014). Menurut Werner R. Murhadi (2013), company size diukur dengan mentrasformasikan total aset yang dimiliki perusahaan ke dalam bentuk logaritma natural (Ln total aset). Variabel muslim di dewan direksi (muslim on board) mengacu pada penelitian Othman et al. (2009), yaitu merupakan prosentase jumlah muslim dan non muslim yang ada di dewan direksi. Variabel wanita di dewan direksi (woman on board) mengacu pada penelitian Gianarrakis (2013), yaitu prosentase jumlah wanita dan laki-laki yang ada di dewan direksi. Jumlah wanita dalam dewan direksi diidentifikasi dari annual report. Variabel usia perusahaan (company's age) mengacu pada penelitian Elshabasy (2018), Lestari (2013), Raditya (2012), yaitu nilai selisih antara tahun penelitian dengan tahun pencatatan atau tahun IPO (first issue) di BEI. Variabel kepemilikan asing (foreign ownership) mengacu pada penelitian Siregar dan Bachtiar (2010), yaitu prosentase jumlah kepemilikan saham oleh investor asing dan investor dalam negeri. Variabel efek syariah perusahaan mengacu pada penelitian Putri, Yuyetta (2014) Raditya (2012), Hossain et al. (2006), Noegraheni (2005), Marwata (2001) yaitu prosentase jumlah sukuk terhadap total hutang jangka panjang yang dimiliki oleh perusahaan.Variabel profitabilitas mengacu pada penelitian Astuti (2013), yaitu menggunakan rasio Return On Asset (ROA) yang diukur dengan perbandingan antara laba bersih setelah pajak dengan total aset. Variabel likuiditas mengacu pada penelitian Astuti (2013), yaitu menggunakan rasio Current Ratio (CR) yang diukur dengan perbandingan antara aset lancar dengan kewajiban lancar.Variabel leverage dalam penelitian ini mengacu pada penelitian Astuti (2013), yaitu menggunakan rasio Debt to Asset Ratio (DAR) yang diukur dengan perbandingan antara total hutang dengan total aset. Pengujian hipotesis dilakukan dengan menggunakan Model Regresi Data Panel. Model regresi data panel dalam penelitian ini dapat diformulasikan sebagai berikut:

$$
\begin{aligned}
& \mathrm{ISR}_{\text {it }}=\alpha+\beta_{1} \mathrm{TA}_{\text {it }}+\beta_{2} \mathrm{DDM}_{\text {it }}+\beta_{3} \mathrm{WD}_{\mathrm{it}}+\beta_{4} \mathrm{UPER}_{\mathrm{it}}+\beta_{5} \mathrm{ASING}_{\mathrm{it}}+\beta_{6} \mathrm{EFEKSYA}_{\mathrm{it}}+ \\
& \beta_{7} \mathrm{ROA}_{\mathrm{it}}+\beta_{8} \mathrm{CR}_{\mathrm{it}}+\beta_{9} \mathrm{DAR}_{\mathrm{it}}+\varepsilon \text { it } \\
& \text { ISR } \quad=\text { Islamic Social Responsibility } \\
& \text { TA } \quad \text { Ukuran perusahaan } \\
& \text { DDM = Muslim di dewan direksi } \\
& \text { WD } \quad=\text { Wanita di dewan direksi } \\
& \text { UPER = Usia perusahaan }
\end{aligned}
$$




$\begin{array}{ll}\text { ASING } & =\text { Kepemilikan asing } \\ \text { EFEKSYA } & =\text { Efek perusahaan } \\ \text { ROA } & =\text { Profitabilitas } \\ \text { CR } & =\text { Likuiditas } \\ \text { DAR } & =\text { Leverage } \\ \mathrm{i} & =\text { Perusahaan sampel }(\mathrm{i}=1,2,3, \ldots) \\ \mathrm{t} & =\text { Tahun } 2015,2016,2017 \\ \alpha & =\text { Konstanta } \\ \beta_{1}-\beta_{10} & =\text { Slope }(\text { kooefisien regresi) } \\ \varepsilon & =\text { Komponen } \text { error }\end{array}$

\section{HASIL DAN PEMBAHASAN}

Berdasarkan hasil content analysis, selama tahun 2011-2017, perusahaan sektor industri barang konsumsi mengalami peningkatan nilai ISR. Pada tahun 2011 nilai ISR 471 pokok pengungkapan, tahun 2012 nilai ISR 490 pokok pengungkapan, tahun 2013 nilai ISR 503 pokok pengungkapan, tahun 2014 nilai ISR 511 pokok pengungkapan, tahun 2015 nilai ISR 524 pokok pengungkapan, tahun 2016 nilai ISR 524 pokok pengungkapan, dan tahun 2017 nilai ISR 534 pokok pengungkapan. Hal ini berarti tingkat pengungkapan tanggung jawab sosial secara syariah setiap perusahaan berbeda-beda. Ada perusahaan yang melakukan pengungkapan tanggung jawab sosial secara syariah dengan baik, namun ada pula perusahaan yang melakukan pengungkapan tanggung jawab sosial secara syariah dengan sangat minim meskipun perusahaan tersebut telah dikategorikan sebagai perusahaan syariah oleh badan otoritas pasar modal dan lembaga keuangan. Tabel 2 menunjukkan bahwa pada perusahaan sektor industri barang konsumsi nilai standar deviasi tertinggi pada variabel usia perusahaan (X4) yaitu sebesar 6,860845 sedangkan nilai standar deviasi terendah dialami oleh variabel ROA (X8) yaitu sebesar 0,158935. Hal ini menjelaskan bahwa standar deviasi merupakan ukuran untuk mengukur disperse atau penyebaran data dan menunjukkan angka yang fluktuatif.

Variabel dependen ISR memiliki nilai mean 22,09317, nilai maksimum 34 dan nilai minimum 11 yang mengindikasikan bahwa rata-rata skor indeks ISR secara keseluruhan setengah dari total pokok pengungkapan indeks ISR. Rata-rata skor indeks ISR secara keseluruhan adalah 22 sedangkan total indeks ISR berjumlah 46 pokok pengungkapan. Dengan demikian, dapat disimpulkan bahwa secara rata-rata perusahaan sektor industri barang konsumsi yang masuk ISSI pada tahun 2011-2017 memiliki tingkat pengungkapan tanggung jawab sossial secara Islam yang cukup dari kriteria ISR. Secara keseluruhan, standar deviasi skor indeks ISR bernilai 6,437004, hal ini mengandung arti bahwa skor indeks ISR menyimpang kurang lebih 6 dari rata-rata skor indeks ISR.

Variabel independen ukuran perusahaan (X1) memiliki nilai mean sebesar 28,14522 dengan nilai maksimum 32,15098 nilai minimum 18,98098, dengan standar deviasi variabel sebesar 1,793461. Hal ini menunjukkan bahwa ukuran perusahaan yang diukur dengan total asset pada sektor industri barang konsumsi yang masuk ISSI pada tahun 2011-2017 relatif beragam. Dimungkinkan total asset perusahaan bernilai rendah karena nature bisnis dari perusahaan tersebut tidak membutuhkan kepemilikan asset yang sangat besar atau perusahaan tersebut masih baru. Variabel independen dewan direksi muslim (X2) memiliki nilai mean sebesar 0,888199 dengan nilai maksimum 1, nilai minimum 0 , dengan standar deviasi variabel sebesar 0,316105. Hal ini menunjukkan bahwa 88,8 perssen perusahaan sektor industri barang konsumsi yang masuk ISSI pada tahun 2011-2017, terdapat muslim dalam dewan direksinya.

Variabel independen wanita dalam direksi (X3) memiliki nilai mean sebesar 0,540373 dengan nilai maksimum 1 , nilai minimum 0 , dengan standar deviasi variabel sebesar 0,499922. Hal ini menunjukkan bahwa 54 persen perusahaan sektor industri barang konsumsi yang masuk ISSI pada tahun 2011-2017 terdapat wanita dalam dewan direksinya. Variabel independen usia perusahaan (X4) memiliki nilai mean sebesar 18,78261 dengan nilai maksimum 35, nilai minimum 1, dengan standar deviasi variabel sebesar 6,860845. Hal ini menunjukkan bahwa 
secara keseluruhan rata-rata umur perusahaan sektor industri barang konsumsi yang masuk ISSI pada tahun 2011-2017 adalah 18 tahun dengan tingkat variabilitas sebesar 6 tahun. Dalam penelitian ini, umur perusahaan-perusahaan yang masuk ISII pada tahun 2011-2017 berada pada kisaran 1 sampai 35 tahun.

Variabel independen kepemilikan asing (X5) memiliki nilai mean sebesar 0,639752 dengan nilai maksimum 1 , nilai minimum 0 , dengan standar deviasi variabel sebesar 0,48157 . Hal ini menunjukkan bahwa dari 63 persen dari perusahaan sektor industri barang konsumsi yang masuk ISSI pada tahun 2011-2017, sahamnya dimiliki oleh institusi atau personal asing. Variabel independen efek syariah perusahaan (X6) memiliki nilai mean sebesar 0,074534 dengan nilai maksimum 1, nilai minimum 0, dengan standar deviasi variabel sebesar 0,263458. Hal ini menunjukkan bahwa hanya 7 persen dari perusahaan sektor industri barang konsumsi yang masuk ISSI pada tahun 2011-2017 menerbitkan atau memiliki sukuk sebagai salah satu sumber pendanaannya.

Variabel independen profitabilitas perusahaan (X7) yang diukur dengan rasio ROA memiliki nilai mean sebesar 0,133362 dengan nilai maksimum 0,79 , nilai minimum $-0,0971$, dengan standar deviasi variabel sebesar 0,158935. Hal ini menunjukkan bahwa rata-rata nilai ROA seluruh perusahaan sektor industri barang konsumsi yang masuk ISSI pada tahun 20112017 adalah 13 persen, artinya bahwa kemampuan perusahaan untuk menghasilkan laba bersih dari setiap satu rupiah asset yang digunakan adalah 13 persen, nilai ROA terendah adalah -9 persen, dan tertinggi 79 persen. Nilai standar deviasi ROA 15,9 persen menunjukkan bahwa nilai ROA mengalami penyimpangan sebesar kurang lebih 15,9 persen dari rata-rata nilai ROA secara keseluruhan.

Variabel independen likuiditas perusahaan (X8) yang diukur dengan rasio lancar (current ratio) memiliki nilai mean sebesar 2,460898 dengan nilai maksimum 7,726, nilai minimum 0,0048 , dengan standar deviasi variabel sebesar 1,470563 . Hal ini menunjukkan bahwa rata-rata nilai CR sektor industri barang konsumsi yang masuk ISSI pada tahun 2011-2017 adalah 246 persen, artinya bahwa perusahaan tersebut punya kemampuan yang baik dalam melunasi kewajibannya, yaitu setiap Rp 1,00 hutang lancar di jamin atau di tanggung oleh Rp 2,46 aktiva lancar. Nilai CR terendah adalah 4,8 persen dan tertinggi 772 persen. Nilai standar deviasi CR 147 persen menunjukkan bahwa nilai CR mengalami penyimpangan sebesar kurang lebih 147 persen dari rata-rata nilai CR secara keseluruhan.

Variabel independen leverege perusahaan (X9) yang diukur dengan Debt to Total Assets Ratio (DAR) memiliki nilai mean sebesar 0,370852 dengan nilai maksimum 0,805 , nilai minimum 0,002 , dengan standar deviasi variabel sebesar 0,187336 . Hal ini menunjukkan bahwa rata-rata nilai DAR perusahaan sektor industri barang konsumsi yang masuk ISSI pada tahun 2011-2017 adalah 33,8 persen, artinya bahwa perusahaan memiliki kemampuan menutup utangnya dengan 37 persen aktiva perusahaan. Nilai DAR terendah adalah 0 persen dan tertinggi 80 persen. Nilai standar deviasi DAR 18,7 persen menunjukkan bahwa nilai DAR mengalami penyimpangan sebesar kurang lebih 18,7 persen dari rata-rata nilai DAR secara keseluruhan.

Tabel 2. Statistik Deskriptif Variabel Penelitian Perusahaan Sektor Industri Barang Konsumsi

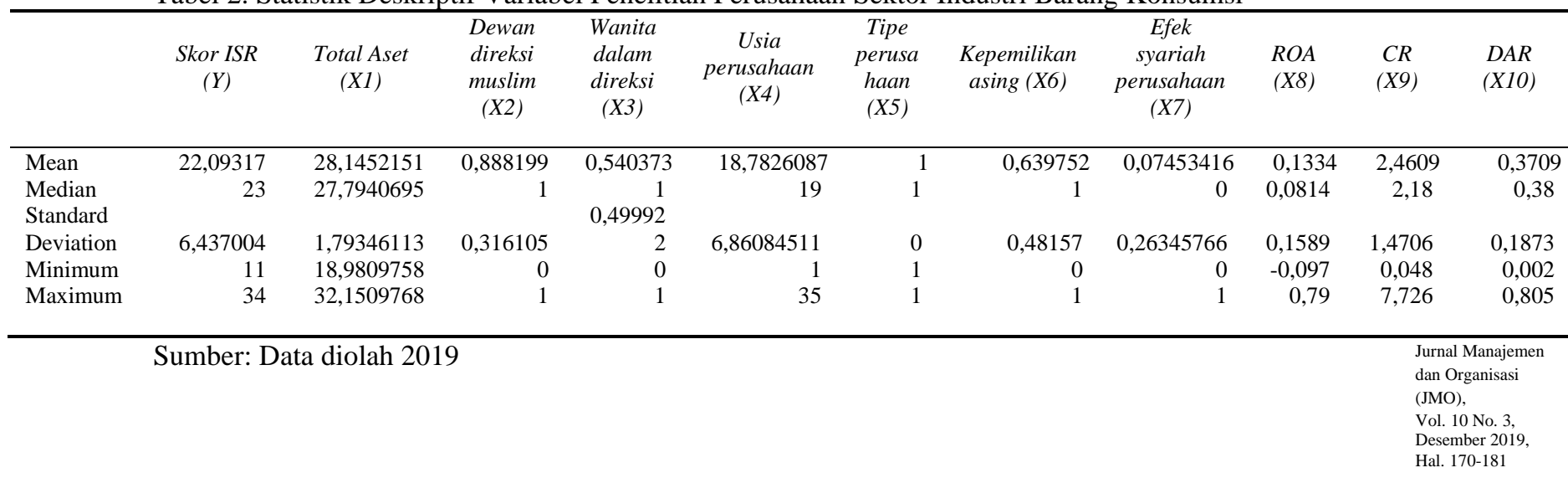


Tabel 3 menunjukkan hasil pengujian hipotesis yang dilakukan dengan menggunakan Model Regresi Data Panel. Berdasarkan hasil uji statistik regresi tersebut, dapat disusun persamaan matematis dari penelitian ini sebagai berikut:

$$
\begin{gathered}
\text { ISR }=-2,147+0,650 \mathrm{ta}-2,305 \mathrm{ddm}-0,332 \mathrm{wd}+1,663 \text { uper }-0,241 \text { asing }+ \\
0,850 \text { efeksya }+3,124 \mathrm{roa}+0,640 \mathrm{cr}+4,561 \mathrm{dar}
\end{gathered}
$$

Berdasarkan Tabel 3 dapat diketahui bahwa ukuran perusahaan (ta) memiliki koefisien $\beta$ bernilai positif 0,6506064 dengan nilai signifikansi 0,016 lebih kecil dari 0,05 sehingga hipotesis satu (H1) diterima. Hal ini berarti bahwa ukuran perusahaan terbukti berpengaruh positif dan signifikan terhadap pengungkapan ISR. Hal ini sesuai dengan teori stakeholders, dimana perusahaan yang besar biasanya memiliki aktivitas yang lebih banyak dan kompleks, mempunyai dampak yang lebih besar terhadap masyarakat, memiliki shareholder yang lebih banyak, serta mendapat perhatian lebih dari kalangan publik, sehingga perusahaan besar mendapat tekanan yang lebih untuk mengungkapkan pertanggungjawaban sosialnya (Cowen et al., 1987) dalam (Siregar \& Bactiar, 2010). Hasil penelitian ini bertolak belakang dengan penelitian terdahulu yang telah dilakukan oleh Othman et al., (2009), Raditya (2012), Lestari (2013), Putri dan Yuyetta (2014), Novrizal dan Fitri (2016), yang menyatakan bahwa ukuran perusahaan positif dan signifikan mempengaruhi pengungkapan ISR. Namun penelitian ini sejalan dengan penelitian sebelumnya yaitu Aly et al., (2010), Ezat dan El-Masry (2008), Hassan et al. (2006), Reverte (2009), Samaha et al. (2011), Samaha dan Dahawy (2010) dan Hussainy et.al. (2011), menemukan bahwa ukuran perusahaan tidak mendorong pengungkapan CSR.

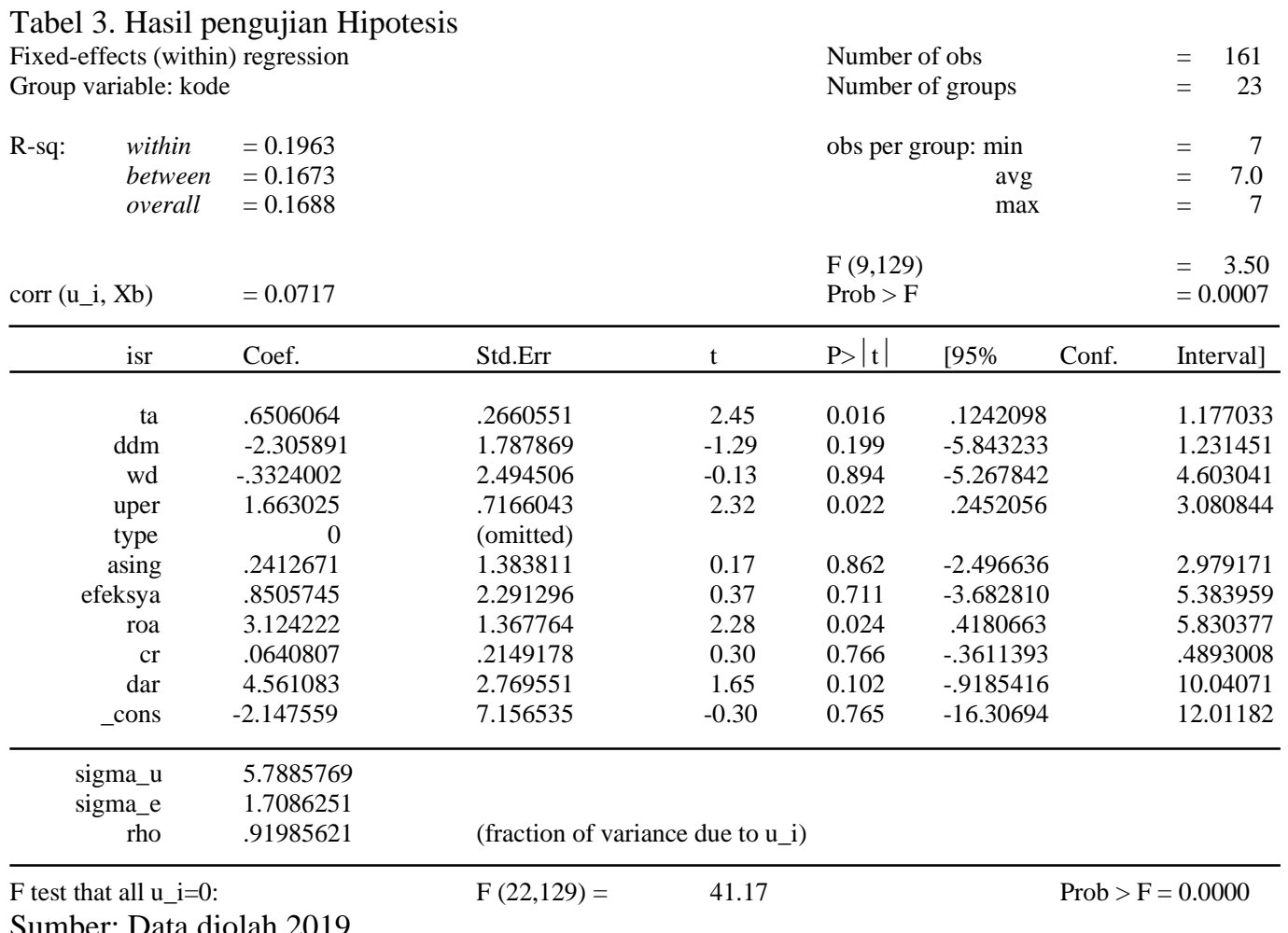

Jurnal Manajemen dan Organisasi (JMO),

Vol. 10 No. 3, Desember 2019

Muslim di dewan direksi (ddm) berpengaruh negatif 2,305891 dan nilai signifikansi 0,199 lebih besar dari 0,05 sehingga hipotesis dua (H2) ditolak. Hal ini berarti bahwa variabel muslim di dewan direksi terbukti berpengaruh negatif dan tidak signifikan terhadap pengungkapan ISR. Hal ini terjadi dimungkinkan karena jumlah muslim di dewan direksi lebih sedikit dibanding jumlah nonmuslim di dewan direksi, dimana ukuran dewan direksi yang besar, memberikan diversitas pengalaman dan pemahaman yang lebih banyak pada dewan direksi, sehingga dewan direksi mempunyai pertimbangan yang lebih baik (Setiawan et al., 2018). Hasil dari penelitian ini bertolak belakang dengan hasil penelitian Othman et al. (2009), yang menyatakan bahwa 
dewan direksi muslim yang merupakan bagian dari komposisi direksi di Malaysia yang memiliki peran dalam pengawasan, memiliki dominasi dan kekuatan yang lebih besar untuk memaksa manajemen dalam pengungkapan ISR.

Wanita di dewan direksi (wd) berpengaruh negatif 0,3324002 dan nilai signifikansi 0,894 lebih besar dari 0,05 sehingga hipotesis tiga (H3) ditolak. Hal ini berarti bahwa variabel wanita dalam dewan terbukti berpengaruh negatif dan tidak signifikan terhadap pengungkapan ISR. Diduga karena wanita kurang menyukai risiko daripada pria, sehingga wanita memiliki persentase yang rendah dalam beberapa jabatan daripada pria (Charness \& Gneezy 2004). Selain itu mungkin karena wanita yang aktif pada ruang publik, mempunyai peran ganda yaitu sebagai ibu rumah tangga dan wanita karier sehingga peran tersebut diduga dapat mempengaruhi kinerja (Zulaikha, 2006) dalam Fathonah (2018). Hasil penelitian ini sejalan dengan penelitian Khan, 2010, yang mana tidak menemukan hubungan yang signifikan antara representasi perempuan di dewan direksi dan pelaporan CSR. Hal ini bertolak belakang dengan hasil penelitian tersebut yang dilakukan oleh Carter et al. (2003), Daily dan Dalton (2003), Zhang et al. (2013), Webb (2004), Wang dan Coffey (1992), Williams (2003), Bernardi et al., (2006), Bear et al. (2010).

Usia perusahaan (wd) berpengaruh positif 1,663025 dan nilai signifikansi 0,022 lebih kecil dari 0,05 sehingga hipotesis empat (H4) diterima. Hal ini berarti bahwa variabel umur perusahaan terbukti berpengaruh positif dan signifikan terhadap pengungkapan ISR. Ini berarti semakin tua usia perusahaan, maka akan semakin luas pengungkapan ISR. Perusahaan dengan usia yang lebih muda kemungkinan akan melakukan pengungkapan yang lebih luas untuk menunjukkan kepatuhan mereka terhadap aturan (Haniffa \& Cooke, 2002). Menurut Akhtaruddin (2005), perusahaan dengan umur yang lebih tua akan cenderung mengungkapkan informasi yang lebih banyak dalam laporan tahunannya dengan tujuan untuk meningkatkan reputasi dan citra perusahaan di pasar. Hasil penelitian ini sejalan dengan penelitian terdahulu yang telah dilakukan oleh Liu dan Anbumozhi (2009), dan Choi (1999) sekaligus menolak hasil penelitian yang telah dilakukan Elshabasy (2018), yang menyatakan bahwa usia perusahaan tidak berpengaruh terhadap pengungkapan laporan sosial, khususnya informasi Lingkungan. Lestari (2013) dan Raditya (2012), menyatakan bahwa usia perusahaan tidak berpengaruh terhadap pengungkapan ISR.

Kepemilikan asing (asing) berpengaru positif 0,2412671 dan nilai signifikansi 0,862 lebih besar dari 0,05 sehingga hipotesis lima (H5) ditolak. Hal ini berarti bahwa variabel kepemilikan asing terbukti berpengaruh positif dan tidak signifikan terhadap pengungkapan ISR. Hal ini diduga karena ketidakmampuan investor asing untuk melakukan pemantauan yang lebih besar karena tingkat kepemilikan yang lebih rendah atau investor asing tidak terlalu peduli dengan ISR karena cakrawala investasi jangka pendek mereka di perusahaan publik di Indonesia. Hasil penelitian ini sejalan dengan penelitian terdahulu yang telah dilakukan oleh Siregar dan Bachtiar (2010), sekaligus membantah hasil penelitian yang tela dilakukan Schipper (1981), Bradbury (1991), Craswell dan Taylor (1992), yang menyatakan bahwa investor asing akan menuntut pengungkapan yang lebih tinggi.

Efek syariah perusahaan (efeksya) berpengaruh positif 0,8505745 dan nilai signifikansi 0,711 lebih besar dari 0,05 sehingga hipotesis enam (H6) ditolak. Hal ini berarti bahwa variabel efek syariah perusahaan terbukti berpengaruh positif dan tidak signifikan terhadap pengungkapan ISR. Salah satu faktor yang menyebabkan penerbitan sukuk mempunyai pengaruh yang tidak signifikan terhadap tingkat pengungkapan Islamic Social Reporting adalah struktur kepemilikan perusahaan di Asia, termasuk Indonesia cenderung family ownership concentration, masih sangat minimnya perusahaan syariah di Indonesia yang menjadikan sukuk sebagai salah satu sumber pendanaan mereka sehingga kesadaran antara perusahaan yang menerbitkan sukuk dengan perusahaan yang tidak menerbitkan sukuk relatif tidak ada perbedaan dalam hal melakukan pengungkapan tanggung jawab sosial yang sesuai dengan prinsip Islam. Hasil penelitian ini sejalan dengan penelitian terdahulu yang telah dilakukan oleh Raditya (2012), sekaligus membantah hasil penelitian yang telah dilakukan Marwata (2001), Noegraheni (2005), Hossain et al. (2006) membuktikan bahwa penerbitan sekuritas berpengaruh signifikan terhadap tingkat 
pengungkapan sukarela perusahaan, serta penelitian Putri dan Yuyetta (2014), yang menemukan bahwa sekuritas syariah positif signifikan berpengaruh dalam pengungkapan ISR di Indonesia.

Profitabilitas (roa) berpengaruh positif 3,124222 dan nilai signifikansi 0,024 lebih kecil dari 0,05 sehingga hipotesis tujuh $(\mathrm{H} 7)$ diterima. Hal ini berarti bahwa variabel profitabilitas terbukti berpengaruh positif dan signifikan terhadap pengungkapan ISR. Perusahaan dengan profit yang lebih tinggi memiliki kecenderungan melakukan intervensi kebijakan. Profitabilitas merupakan faktor yang membuat manajemen menjadi bebas dan fleksibel untuk mengungkapkan pertanggungjawaban sosial kepada pemegang saham. Dalam perspektif Islam, sebuah perusahaan harus bersedia memberikan pengungkapan penuh tanpa menghiraukan apakah itu menghasilkan keuntungan atau sebaliknya. Hasil penelitian ini sejalan dengan penelitian terdahulu yang telah dilakukan oleh Othman et al. (2009) dan Raditya (2012), sekaligus membantah hasil penelitian yang telah dilakukan Aulia (2010) menemukan bahwa profitabilitas tidak berpengaruh signifikan terhadap CSR, Astuti (2013), Rosiana, Arifin, dan Hamdani (2015), Novrizal dan Fitri (2016), yang menyatakan bahwa profitabilitas tidak berpengaruh terhadap pengungkapan Islamic Social Report.

Likuiditas (cr) berpengaruh negatif 0,640807 dan nilai signifikansi 0,766 lebih besar dari 0,05 sehingga hipotesis delapan (H8) ditolak. Hal ini berarti bahwa variabel likuiditas terbukti berpengaruh negatif dan tidak signifikan terhadap nilai ISR pada perusahaan sektor industri barang konsumsi yang terdaftar di Indeks Saham Syariah Indonesia (ISSI). Hasil penelitian ini sejalan dengan penelitian terdahulu yang telah dilakukan oleh Mudjiyanti dan Maulani (2017), Rosyadi (2015), Hussainey et al. (2011), Syahrir dan Suhendra (2010) dalam Mudjiani dan Maulani (2017), membuktikan bahwa likuiditas berpengaruh positif terhadap pengungkapan CSR, dan menurut penelitian Astuti (2013), likuiditas perusahaan memiliki berpengaruh pada pengungkapan Islamic Social Report (ISR).

Leverage (dar) berpengaruh positif 4,561083 dan nilai signifikansi 0,102 lebih besar dari 0,05 sehingga hipotesis sembilan (H9) ditolak. Hal ini berarti bahwa variabel leverage terbukti berpengaruh positif dan tidak signifikan terhadap pengungkapan ISR. Perusahaan dengan leverage yang tinggi mengandung biaya pengawasan (monitoring cost) tinggi, hal ini menunjukkan bahwa jika perusahan memiliki leverage yang tinggi maka perusahaan akan menyediakan informasi yang lebih komprehensif. Seperti halnya dalam teori keagenan yang memprediksi bahwa perusahaan dengan rasio leverege yang lebih tinggi akan mengungkapkan lebih banyak informasi.Hasil penelitian ini sejalan dengan penelitian terdahulu yang telah dilakukan oleh Rosiana, Arifin, dan Hamdani (2015) yang menyatakan bahwa leverage tidak berpengaruh dalam pengungkapan ISR sekaligus membantah hasil penelitian yang telah dilakukan Astuti (2013), leverage perusahaan berpengaruh signifikan pada pengungkapan Islamic Social Report.

\section{KESIMPULAN}

Dari sembilan variabel yang diteliti yaitu ukuran perusahaan (company's size), muslim di dewan direksi (muslim on board), wanita di dewan direksi (woman on board), usia perusahaan (company's age), kepemilikan asing (foreign ownership), efek syariah perusahaan (Islamic securities), profitabilitas (profitability), likuiditas (liquidity), dan leverage (leverage), terbukti hanya ukuran perusahaan (company's size), usia perusahaan (company's age), dan profitabilitas (profitability) yang berpengaruh terhadap pengungkapan Islamic Social Report (ISR) pada Perusahaan Sektor Industri Barang Konsumsi yang terdaftar di Indonesia Sharia Stock Index (ISSI) Bursa Efek Indonesia (BEI) dalam rentang tahun 2011-2017. Hal ini menunjukkan bahwa semakin besar ukuran perusahaan, semakin tua usia perusahaan dan semakin besar profit perusahaan, semakin lebih banyak melakukan pengungkapan Islamic Social Report (ISR). Muslim di dewan direksi (muslim on board) tidak berpengaruh terhadap pengungkapan ISR dimungkinkan jika jumlah muslim di dewan direksi sedikit, sehingga kurang mempengaruhi keputusan manajerial dalam pengungkapan ISR. Wanita di dewan direksi (woman on board) tidak berpengaruh terhadap pengungkapan ISR dimungkinkan karena wanita kurang menyukai risiko 
daripada pria sehingga wanita memiliki persentase rendah dalam jabatan, pengambilan keputusan daripada pria. Selain itu wanita yang aktif pada ruang publik mempunyai peran ganda yaitu sebagai ibu rumah tangga, dan wanita karier sehingga diduga mempengaruhi kinerja. Kepemilikan asing (foreign ownership) tidak berpengaruh terhadap pengungkapan ISR dimungkinkan terjadi karena tingkat kepemilikan yang lebih rendah, kepemilikan jangka pendek, atau investor asing tidak terlalu peduli dengan ISR sehingga mempengaruhi investor asing dalam melakukan pemantauan yang lebih besar tentang ISR. Efek syariah perusahaan (Islamic securities) tidak berpengaruh terhadap pengungkapan ISR dimungkinkan besaran sukuk yang dimiliki perusahaan sektor industri barang konsumsi, tidak mempengaruhi pengungkapan ISR di laporan tahunannya. Likuiditas (liquidity) dan Leverage (leverage) tidak berpengaruh terhadap pengungkapan ISR, dimungkinkan rendah atau tinggi rasio likuiditas dan leverage perusahaan sektor industri barang konsumsi tidak mempengaruhi pengungkapan ISR di laporan tahunannya, dan dalam perspektif Islam, perusahaan harus bersedia memberikan pengungkapan penuh tanpa menghiraukan apakah memiliki rasio likuiditas dan leverege tinggi atau rendah.

Implikasi dari hasil penelitian ini adalah bahwa perusahaan yang memiliki ukuran perusahaan (company's size) yang besar, usia perusahaan (company's age) yang lebih tua, dan profitabilitas (profitability) lebih besar, namun belum mengungkapkan diharapkan segera mengungkapan Islamic Social Report (ISR), dan bagi perusahaan yang sudah melakukan pengungkapan ISR diharapkan lebih meningkatkan kesadarannya untuk mengungkapkan Islamic Social Report (ISR) dalam laporan tahunannya. Keterbatasan dari penelitian ini pertama, penelitian dilakukan hanya pada sektor industri barang konsumsi yang terdaftar pada ISSI selama tahun 2011-2017. Jumlah sampel yang terbatas karena hanya 23 perusahaan sektor industri barang konsumsi yang memungkinkan ketidakakuratan dalam melakukan estimasi terhadap populasi. Kedua, objek yang dipilih bukan termasuk perusahaan syariah, namun merupakan perusahaan yang menghasilkan produk sesuai dengan ketentuan syariah. Ketiga, sumber informasi yang dijadikan sebagai bahan penilaian pengungkapan tanggung jawab sosial secara syariah hanya terbatas pada laporan tahunan perusahaan yang bersangkutan.

Dengan adanya keterbatasan tersebut diharapkan penelitian selanjutnya dapat memperbaiki penelitian ini. Pertama, perlu dilakukan penelitian lebih lanjut mengenai pengungkapan ISR sesuai dengan jenis industri lainnya, sesuai dengan Fact Book IDX, dan masuk dalam Indonesia Sharia Stock Index (ISSI) sehingga penelitian selanjutnya dapat lebih menggambarkan kondisi pasar modal syariah yang sebenarnya. Kedua, penelitian selanjutnya harus mengembangkan pokok-pokok pengungkapan indeks ISR secara lebih komprehensif dengan tidak lupa memperhatikan karakteristik dan kondisi di Indonesia, agar indeks ISR dapat lebih merefleksikan tanggung jawab sosial yang sesuai dengan prinsip Islam dan dapat diterapkan di Indonesia. Ketiga, metode content analysis dalam penelitian ini penuh dengan unsur subjektivitas dalam melakukan interpretasi terhadap pokok pengungkapan, oleh karena itu penelitian selanjutnya mungkin dapat menggunakan metode content analysis lain yang dapat mengurangi tingkat subjektivitas terhadap informasi yang disajikan oleh perusahaan dalam laporan-laporannya. Keempat, penelitian berikutnya diharapkan menambah sumber informasi yang dijadikan sebagai bahan penilaian pengungkapan tanggung jawab sosial secara syariah, seperti press release, informasi yang diungkapkan di situs web perusahaan, dan sumber informasi lain.

\section{DAFTAR PUSTAKA}

Aini, A. K. (2015). Pengaruh Karakteristik Perusahaan terhadap Pengungkapan Tanggungjawab Sosial Perusahaan (CSR) pada Perusahaan yang terdaftar di Indeks LQ45 Bursa Efek Indonesia (BEI). Jurnal Kinerja, 12(1), 1-11.

Akhtaruddin, M. (2005). Corporate Mandatory Disclosure Practices in Bangladesh. The International Journal of Accounting, 40, 399-422.

Astuti, E. P. (2013). Pengaruh Diversitas Dewan Direksi terhadap Nilai Perusahaan pada Perusahaan Manufaktur yang terdaftar di Bursa Efek Indonesia Periode 2008-2011. Kreatif, Jurnal Ilmiah Prodi Manajemen Universitas Pamulang, 4(2), 159-179.

Jurnal Manajemen dan Organisasi (JMO),

Vol. 10 No. 3 , 
Bear, S., Rahman, N., \& Post, C. (2010). The Impact of Board Diversity and Gender Composition on Corporate Social Responsibility and Firm Reputation. Journal of Business Ethics, 97, 207-221. (DOI 10.1007/s10551-010-0505-2).

Bradbury, M. E. (1991). Characteristics of Firms and Voluntary Interim Earnings Disclosure: New Zealand Evidence. Pacific Accounting Review, 3, 37-62.

Carter, D. A., Simkins, B. J. \& Simpson, W. G. (2003). Corporate Governance, Board Diversity, and Firm Value. Financial Review, 38(1), 33-53.

Choi, J. (1999). An Investigation of The Initial Voluntary Environmental Disclosures Made in Korean Semi-Annual Financial Reports. Pacific Accounting Review, 73-102.

Cowen, S., Ferrari, L. \& Parker, L. (1987). The Impact of Corporate Characteristics on Social Accounting Disclosure: A Topology and Frequency Based Analysis. Accounting, Organisations and Society, 12(2), 111-122.

Craswell, A. \& Taylor, S. (1992). Discretionary Disclosure of Reserves by Oil and Gas Companies: An Economic Analysis, Journal of Business Finance \& Accounting, 19, 295 308.

Daily, C. M. \& Dalton, D. R. (2003). Women in The Boardroom: A Business Imperative, Journal of Business Strategy, 24(5), hal. 8-9.

Elshabasy, Y. N. (2018). The Impact of Corporate Characteristics on Environmental Information Disclosure: An Empirical Study on The Listed Firms in Egypt. International Journal of Business and Retail Management Research (JBRMR), 12(2), 232-241.

Fathonah, A. N. (2018). The Effects of Gender Diversity and Age Diversity on Financial Performance. Jurnal Riset Akuntansi dan Keuangan, 373-380. (DOI: 10.17509/jurnal jrak.v4i1.7705).

Giannarakis, Grigoris. (2014). The Determinants Influencing the Extent of CSR Disclosure. International Journal of Law and Management Vol. 56 No. 5, hal. 393-416. DOI 10.1108/IJLMA-05-2013-0021.

Haniffa, R. (2002). Social Reporting Disclosure-An Islamic Perspective. Indonesian Management \& Accounting Research, 128- 146.

Hossain, M., Islam, K., \& Andrew, J. (2006). Corporate Social and Environmental Disclosure in Developing Countries: Evidence from Bangladesh. Asian Pacific Conference on International Accounting Issues, Hawaii: Research Online University of Wollongong, 122.

Hussainey, K., Mohamed, E., Razik, A. A. (2011). Factors Affecting Corporate Social Responsibility Disclosure in Egypt. Ownership and Control.

Lestari, P. (2013). Determinants of Islamic Social Reporting in Syariah Banks: Case of Indonesia. International Journal of Business and Management Invention, 2, 28-34.

Liu, X. \& Anbumozhi, V. (2009). Determinant Factors of Corporate Environmental Information Disclosure: An Empirical Study of Chinese Listed Companies. Journal of Cleaner Production, 593-600.

Marwata. (2001). Hubungan Antara Karakteristik Perusahaan dan Kualitas Ungkapan Sukarela dalam Laporan Tahunan Perusahaan Publik di Indonesia. Simposium Nasional Akuntansi 4, hal. 155-173.

Mathews, M. R. (1995). Social and environmental accounting: a practical demonstration of ethical concern. Journal of Business Ethics, 14(8), 663-671.

Noegraheni. (2005). Pengaruh Karakteristik Perusahaan terhadap Kualitas Pengungkapan Sukarela dalam Laporan Tahunan pada Perusahaan Publik Non Industri Keuangan di Bursa Efek Jakarta. Equity, 2, 61-70.

Novrizal, M. F., \& Fitri, M. (2016). Faktor-Faktor yang Mempengaruhi Pengungkapan Corporate Social Responbility (CSR) pada Perusahaan yang Terdaftar di Jakarta Islamic Index (JII) tahun 2012- 2015 dengan Menggunakan Islamic Social Reporting (ISR) Index sebagai Tolok Ukur. Jurnal Ilmiah Mahasiswa Ekonomi Akuntansi (JIMEKA), 1(2), 177-189.

Othman, R., \& Thani, A. M. (2010). Islamic Social Reporting of Listed Companies in Malaysia. International Business \& Economics Research Journal, 12, 135-144. 
Othman, R., Thani, A. M., \& Ghani, E. K. (2009). Determinants of Islamic Social Reporting Among Top Shariah-Approved Companies in Bursa Malaysia. Research Journal of International Studies, 9, 4-20.

Putri, T. K. \& Yuyetta, E. N. A. (2014). Faktor-Faktor yang mempengaruhi Islamic Social Reporting yang Terdaftar di ISSI tahun 2011-2012. Diponegoro Journal of Accounting, 2(2), 356-368.

Raditya, A. N. (2012). Pengungkapan Islamic Social Reporting (ISR) pada Perusahaan yang Masuk Daftar Efek Syariah (DES). Skripsi, Universitas Indonesia, Jakarta.

Rosiana, R., Bustanul, A., \& Muhamad, H. (2015). Pengaruh Ukuran Perusahaan, Profitabilitas, Leverage, dan Islamic Governance Score terhadap Pengungkapan Islamic Social Reporting: Studi Empiris pada Bank Umum Syariah di Indonesia Tahun 2010-2012. Jurnal Bisnis dan Manajemen, 5(1), 87-104.

Schipper, K. (1981). Discussion of voluntary corporate disclosure: the case of interim reporting. Journal of Accounting Research, 19, 85-8 (Supplement).

Setiawan, D., Hapsari, R. T., Wibawa, A. (2018). Dampak Karakteristik Dewan Direksi terhadap Pengungkapan Corporate Social Responsibility pada Perusahaan Pertambangan di Indonesia. Jurnal Ilmiah Manajemen, 8(1), 1-15. (DOI: dx.doi.org/10.22441/mix.2018.v8i1.001).

Siregar, S. V. \& Yanivi, B. (2010). Corporate Social Reporting: Empirical Evidence from Indonesia Stock Exchange, International Journal of Islamic and Middle Eastern Finance and Management, 3(3), 241-25. (DOI 10.1108/17538391011072435).

Syukron, A. (2015). CSR dalam Perspektif Islam dan Perbankan Syariah. Economic: Jurnal Ekonomi dan Hukum Islam, 5(1), 1-22.

Wang, J. \& Coffey, B. S. (1992). Board composition and corporate philanthropy. Journal of Business Ethics, 11(10), 771-778.

Webb, E. (2004), An examination of socially responsible firm's board structure. Journal of Management and Governance, 8(3), 255-277.

Williams, R. J. (2003). Women on Corporate Boards of Directors and Their in Uence on Corporate Philanthropy. Journal of Business Ethics, 42(1), 1-10.

Zhang, J. Q., Zhu, H. \& Ding, H. B. (2013). Board Composition and Corporate Social Responsibility: An Empirical Investigation in The Post Sarbanes-oxley Era. Journal of Business Ethics, 114(3), 381-392.

Zulaikha. (2006). Pengaruh Interaksi Gender, Kompleksitas Tugas dan Pengalaman Auditor Terhadap Audit Judgment. Padang: Simposium Nasional Akuntansi IX. 